\title{
CHEVRON AT 30: LOOKING BACK AND LOOKING FORWARD FOREWORD
}

\author{
Peter M. Shane* \& Christopher J. Walker**
}

This year marks the thirtieth anniversary of Chevron U.S.A. v. Natural Resources Defense Council. ${ }^{1}$ This seminal U.S. Supreme Court decision regarding the judicial deference owed to federal agency statutory interpretations is the most-cited administrative law decision of all time: Chevron has been cited in over 68,000 total sources available on Westlaw-including in over 13,500 subsequent judicial decisions, in over 41,000 court filings, and in nearly 12,000 law review articles and secondary sources. $^{2}$ Over the last three decades, courts, litigants, and scholars have addressed numerous Chevron-related questions, such as what Chevron deference means, when (or even if) it should apply, and what impact it has had on the administrative state - just to name a few. To borrow a line from Justice Scalia in a Chevron-related decision, "[i]t is indeed a wonderful new world that the Court creates, one full of promise for administrative law

* Jacob E. Davis and Jacob E. Davis II Chair in Law, The Ohio State University Michael E. Moritz College of Law.

** Assistant Professor of Law, The Ohio State University Michael E. Moritz College of Law.

1. 467 U.S. 837 (1984).

2. To arrive at the conclusion that Chevron is the most cited administrative law decision of all time, we checked the citations on Westlaw for every Supreme Court decision cited in the latest edition of Jerry L. Mashaw, Richard A. Merrill, Peter M. Shane, M. Elizabeth Magill, Mariano-Florentino Cuellar, Nicholas R. Parrillo, Administrative Law: The American Public Law System (7th ed. 2014). Of the over 550 cases reviewed, two cases were cited more than Chevron (as of October 1, 2014): Daubert v. Merrell Dow Pharmaceuticals, Inc., 509 U.S. 579 (1993), with 105,566 total citations; and Harlow v. Fitzgerald, 457 U.S. 800 (1982), with 71,840 total citations. The next two most cited cases after Chevron were Kumho Tire Co., Ltd. v. Carmichael, 526 U.S. 137 (1999), with 53,289 total citations; and Lujan v. Defenders of Wildlife, 504 U.S. 555 (1992), with 48,608 total citations. We do not count Daubert (or Kumho) and Harlow as administrative law cases, as Daubert and Kumho deal primarily with expert-witness qualifications and Harlow addresses qualified and absolute immunity. By comparison, as of October 1, 2014, United States v. Mead Corp., 533 U.S. 218 (2001), had 9,811 total citations; and Skidmore v. Swift \& Co., 323 U.S. 134 (1944), had 11,291 total citations. The full list with citation counts is on file with the authors. Our thanks go to research assistants Justin Nelson and Molly Werhan for compiling these statistics. 
professors in need of tenure articles and, of course, for litigators." 3 But Justice Scalia's statement is too limited. Chevron jurisprudence holds promises and puzzles, too, for already tenured faculty, courts, legislators, and agency officials.

Chevron's thirtieth anniversary provides a fitting moment to reflect on how Chevron and its progeny have shaped and will continue to shape the modern administrative state. To seize this moment, the Fordham Law Review convened a symposium at the Fordham University School of Law on March 7, 2014. A dozen scholars from across the country presented papers, and many more scholars and students participated in the discussion. The live symposium was organized into four panels: (1) Chevron in the Courts, (2) Chevron in Congress, (3) Chevron in the Executive, and (4) Chevron at 30: Big Deal? Good Deal? Bad Deal? ${ }^{4}$ This issue of the Law Review presents the final versions of those papers.

In this Foreword, we introduce the contributions to the symposium and focus on a number of recurring themes that both look back on the first thirty years of Chevron and look forward to the next thirty. The Foreword proceeds as follows:

Part I provides a brief sketch of the development of the Chevron deference regime over the last three decades and explores the continuing uncertainties about Chevron's scope and application, especially after the Court's decision last year in City of Arlington v. FCC. ${ }^{5}$ The vast majority of contributors weighed in on these issues to some extent, with a half dozen focusing extensively on them.

Part II introduces the various contributions that focus on secondgeneration Chevron issues by exploring empirically and theoretically Chevron's impact outside of the judicial review context-i.e., its effect on legislative- and administrative-drafting theory and practice, its influence within the regulatory state more generally, and its adoption (or lack thereof) in state administrative law. These are undertheorized and empirically underexplored areas where no doubt much work will continue to be done over the next thirty years.

Part III turns to another growth area: the intersection of Chevron and federalism. Two contributions focus on the role of federalism in defining the scope of Chevron and how courts and Congress should-or should not-limit Chevron's scope based on the effect such agency action will have on the states.

The Foreword concludes by taking a step back after thirty years and grappling with the contributors' diverse views (including our own) on

3. Nat'l Cable \& Telecomms. Ass'n v. Brand X Internet Servs., 545 U.S. 967, 1019 (2005) (Scalia, J., dissenting).

4. Video of the symposium panels is available on the Law Review's website at http://fordhamlawreview.org. We thank the Fordham University School of Law and the Fordham Law Review for hosting this symposium as well as Professors Abner S. Greene, Clare Huntington, Joseph Landau, and Olivier Sylvain for moderating the panels.

5. 133 S. Ct. 1863 (2013). 
whether Chevron is indeed a big deal and, if so, whether it is a good or bad deal for the modern administrative state.

\section{CHEVRON AFTER THIRTY YEARS: CONTINUED UNCERTAINTY ABOUT SCOPE AND APPLICATION}

The bulk of scholarship on Chevron has focused on its scope, application, and rationales with respect to judicial review of agency statutory interpretations. As the contributions to this symposium nicely illustrate, this line of scholarship is alive and well and will no doubt endure for decades to come - in large part because the Court continues to tinker with the Chevron deference regime.

When Justice Stevens, writing for the Court in 1984, articulated the Chevron two-step approach, at first blush it may have seemed like a fairly straightforward rule that would be easily administrable in the lower courts:

When a court reviews an agency's construction of the statute which it administers, it is confronted with two questions. First, always, is the question whether Congress has directly spoken to the precise question at issue. If the intent of Congress is clear, that is the end of the matter; for the court, as well as the agency, must give effect to the unambiguously expressed intent of Congress. If, however, the court determines Congress has not directly addressed the precise question at issue, the court does not simply impose its own construction on the statute, as would be necessary in the absence of an administrative interpretation. Rather, if the statute is silent or ambiguous with respect to the specific issue, the question for the court is whether the agency's answer is based on a permissible construction of the statute. ${ }^{6}$

This deference rule, Justice Stevens explained, follows from the fact (or perhaps legal fiction) that in such circumstances Congress has explicitly or implicitly "left a gap for the agency to fill . . . by regulation." 7 Such congressional delegation to federal agencies - as opposed to courts - to be the primary interpreters of statutes agencies administer was justified on grounds of comparative expertise of federal agencies in policymaking and reconciling conflicting political interests, and on the comparative political accountability of agencies (as opposed to courts). ${ }^{8}$

In the footnotes accompanying the two-step approach quoted above, Justice Stevens provided some additional, seemingly basic instructions on how the steps should work. As to the first step regarding statutory ambiguity, footnote nine instructs that the reviewing court should "[e]mploy[] the traditional tools of statutory construction" to determine whether "Congress had an intention on the precise question at issue." 9 As to the second step regarding permissibility of the agency's interpretation, footnote eleven states that "[t]he court need not conclude that the agency construction was the only one it permissibly could have adopted to uphold

6. Chevron, 467 U.S. at 842-43 (footnotes omitted).

7. Id. at $843-44$.

8. See id. at 844-45, 864-66.

9. Id. at 843 n.9. 
the construction, or even the reading the court would have reached if the question initially had arisen in a judicial proceeding."10 For the agency's construction of an ambiguous statute to be permissible under Step Two, it simply must be "a reasonable interpretation." 11

As the last thirty years have demonstrated, however, these instructions turned out to be far from easy to follow. As to Step One, questions abound about the traditional tools of statutory construction that should apply. For instance, should more purposivist methodologies - such as legislative history - be used to construe away ambiguities at Step One, or should such inquiry be left to the Step Two reasonableness prong (if anywhere)? ${ }^{12}$ What role should substantive canons, such as constitutional avoidance, play? ${ }^{13}$ Should a prior judicial interpretation of an ambiguous statute play no role at Chevron Step One to limit a subsequent agency statutory interpretation? At least for now, the Court has resolved the last of these questions ${ }^{14}$ - a decision Abbe Gluck notes in her contribution to this symposium as having "enormous repercussions for the allocation of power between courts and agencies."15

Chevron Step Two is similarly not lacking for debate or confusion. For instance, is the Step Two reasonableness inquiry separate and distinct from arbitrary and capricious review under the Administrative Procedure Act ${ }^{16}$ (APA)? In his symposium contribution, Jack Beermann assesses the current state of Step Two, concluding that "the Roberts Court has failed miserably to clarify the boundary between Chevron and other standards of review such as [the APA's] arbitrary or capricious review."17 Indeed, in

10. Id. at 843 n. 11.

11. Id. at 844 .

12. For a recent contribution to this debate, see John F. Manning, Chevron and Legislative History, 82 GEO. WASH. L. REV. (forthcoming 2014).

13. Compare Edward J. DeBartolo Corp. v. Fla. Gulf Coast Bldg. \& Constr. Trades Council, 485 U.S. 568, 575 (1988) (constitutional avoidance trumps Chevron), and Cass R. Sunstein, Nondelegation Canons, 67 U. CHI. L. REv. 315, 330 (2000) (substantive canons trump Chevron), with ADRIAN VERMEUle, JUdging Under UnCERTAINTY: AN INSTITUTIONAL THEORY OF LEGAL INTERPRETATION 211 (2006) (Chevron trumps substantive canons), and Thomas W. Merrill \& Kristin E. Hickman, Chevron's Domain, 89 GEO. L.J. 833, 915 (2001) (Chevron trumps constitutional avoidance), and Christopher J. Walker, Avoiding Normative Canons in the Review of Administrative Interpretations of Law: A Brand X Doctrine of Constitutional Avoidance, 64 ADMIN. L. REV. 139, 143-44 (2012) (same), and with Hernandez-Carrera v. Carlson, 547 F.3d 1237, 1242 (10th Cir. 2008) (constitutional avoidance applies at Chevron Step Two), and Kenneth A. Bamberger, Normative Canons in the Review of Administrative Policymaking, 118 YALE L.J. 64, 93-94 (2008) (substantive canons apply at Chevron Step Two).

14. Nat'l Cable \& Telecomms. Ass'n v. Brand X Internet Servs., 545 U.S. 967, 982-83 (2005).

15. Abbe R. Gluck, What 30 Years of Chevron Teach Us About the Rest of Statutory Interpretation, 83 FORDHAM L. REV. 607, 625 (2014).

16. 5 U.S.C. $\S 706(2)(A)(2012)$.

17. Jack M. Beermann, Chevron at the Roberts Court: Still Failing After All These Years, 83 FORDHAM L. REV. 731, 732 (2014) [hereinafter Beermann, Chevron at the Roberts Court]; accord Jack M. Beermann, End the Failed Chevron Experiment Now: How Chevron Has Failed and Why It Can and Should Be Overruled, 42 ConN. L. REv. 779, 807-08 (2010). 
part because of the apparent overlap between the two steps, there is a growing scholarly debate (with Justice Scalia chiming in ${ }^{18}$ ) about whether Chevron has, or should have, one or two steps. ${ }^{19}$

But the aspect of Chevron that has received the most attention-both in this symposium and in the literature more generally - is a threshold step not expressly articulated in Chevron itself. This "Chevron Step Zero" inquiry, as symposium contributors Thomas Merrill and Kristin Hickman coined it years ago, concerns which agency actions even qualify for Chevron review. ${ }^{20}$ The Court addressed this issue head on in 2001 - at a time when Chevron was a mere teenager-in United States v. Mead Corp. ${ }^{21}$ The Mead Court declared that not all agency action is reviewed under Chevron, but instead there must be evidence of congressional delegation. ${ }^{22}$ The Court noted that "a very good indicator of delegation meriting Chevron treatment [is] express congressional authorizations to engage in the rulemaking or adjudication process that produces the regulations or rulings for which deference is claimed." 23 But the Mead Court further noted that it had "sometimes found reasons for Chevron deference even when no such administrative formality was required and none was afforded." 24 In the absence of such evidence of delegation, the Mead Court indicated that the less deferential review standard articulated in Skidmore v. Swift \& Co. controls. ${ }^{25}$ Under Skidmore, an agency's reasonable interpretation of an ambiguous statute does not control as it would under Chevron; instead, the court gives the agency's interpretation "weight" based on "the thoroughness evident in [the agency's] consideration, the validity of its reasoning, its consistency with earlier and later pronouncements, and all those factors which give it power to persuade." 26

As Kristin Hickman points out in her contribution to this symposium, the elaboration of deference doctrine in the form of "steps" has led the Supreme

18. United States v. Home Concrete \& Supply, LLC, 132 S. Ct. 1836, 1846 n.1 (2012) (Scalia, J., concurring in part and concurring in judgment) (noting that "'Step 1' has never been an essential part of Chevron analysis").

19. See, e.g., Kenneth A. Bamberger \& Peter L. Strauss, Chevron 's Two Steps, 95 VA. L. Rev. 611 (2009); Richard M. Re, Should Chevron Have Two Steps?, 89 InD. L.J. 605 (2014); Matthew C. Stephenson \& Adrian Vermeule, Chevron Has Only One Step, 95 VA. L. Rev. 597 (2009).

20. Merrill \& Hickman, supra note 13, at 836-37 (2001); see also Cass Sunstein, Chevron Step Zero, 92 VA. L. REV. 187, 207-11 (2006).

21. 533 U.S. 218 (2001). As Kristin Hickman further details in her contribution to the symposium, "understanding Mead's aftermath requires viewing Mead not in isolation but as part of a trilogy of cases consisting of Mead, Christensen v. Harris County, and Barnhart v. Walton." Kristin E. Hickman, The Three Phases of Mead, 83 FordHAM L. ReV. 527, 531 (2014).

22. Mead, 533 U.S. at 226-27.

23. Id. at 229.

24. Id. at 231 .

25. Id. at 226-28 (citing Skidmore v. Swift \& Co., 323 U.S. 134 (1944)).

26. Skidmore, 323 U.S. at 140. Peter Strauss has helpfully reframed these deference standards as "Chevron space" and "Skidmore weight." Peter L. Strauss, "Deference" Is Too Confusing-Let's Call Them "Chevron Space" and "Skidmore Weight," 112 Colum. L. REV. 1143, 1144-45 (2012). 
Court and lower courts on many occasions to apply the doctrine as if following a kind of decision tree. ${ }^{27}$ Under this approach, courts ask first, à la Mead, whether the agency issued its challenged interpretation in a context where Congress has delegated to the agency the authority "to speak with the force of law." 28 If the answer is positive, then the agency, à la Chevron, is entitled to judicial deference to any reasonable interpretation it adopts, unless the relevant statute clearly speaks to the issue at hand in a way that precludes the agency's approach. ${ }^{29}$ If the answer is negative, then the agency is entitled only to Skidmore deference. ${ }^{30}$ Conceptualizing deference doctrine in this way holds out the seeming promise of fairly bright-line guidance. Courts could categorically identify certain agency processes - most obviously, formal adjudication and notice-and-comment rulemaking 31 - as entitling the agency to Chevron deference. Statutes might then be divided into those that clearly affirm or preclude the agency reading (Step One cases), on one hand, and legally ambiguous statutes (Step Two cases), on the other.

Uncertainty, however, surrounds every part of this picture. For example, Justice Scalia thinks the Mead inquiry an unnecessary and confusing prelude to Chevron. For Scalia, Chevron applies to any legal interpretation that represents the "authoritative view" of the agency; the "force of law" inquiry is inappropriately limiting. ${ }^{32}$ Because Chevron mandates deference, however, only when the relevant statute is not susceptible to a legally unambiguous reading, this does not-at least in Justice Scalia's casenecessarily augur more frequent deference than if Chevron were limited in the way Mead contemplates. As Professor Hickman notes, that is because, in purporting to apply Chevron, Justice Scalia is so frequently confident that he can divine a statute's clear legal meaning by applying his understanding of the appropriate traditional tools of construction. ${ }^{33}$ Step Two deference is simply irrelevant in cases where judges stop at Step One.

For his part, Justice Breyer-another of the administrative law professors on the Court-would obliterate nearly all the bright-line-ishness of the decision tree. He presumably agrees that a statute susceptible only to a single legally unambiguous reading, based on traditional tools of statutory interpretation, ought to be implemented according to that reading. ${ }^{34}$ In the face of ambiguity, however, he would calibrate the weightiness of deference to be accorded to the agency based on all relevant contextual factors. ${ }^{35}$

\footnotetext{
27. Hickman, supra note 21 , at 537-41.

28. Mead, 533 U.S. at 229.

29. Id.

30. Id. at $234-35$.

31. In City of Arlington v. FCC, 133 S. Ct. 1863, 1874 (2013), the Court clarified that an agency's use of congressionally authorized formal procedures is not just "a very good indicator" of congressional delegation but a sufficient one.

32. Mead, 533 U.S. at 239-40, 258-59 \& n.6 (Scalia, J., dissenting).

33. Hickman, supra note 21, at 545-47.

34. E.g., Nat'l Cable \& Telecomms. Ass'n v. Brand X Internet Servs., 545 U.S. 967, 1003-06 (2005) (Breyer, J., concurring).

35. $I d$.
} 
Strong evidence that Congress did or did not intend to delegate binding interpretive power to an agency would be one of these factors, but it would not necessarily be controlling either way. As Professor Hickman notes, cases exist that appear to track the Breyer approach more than they do any decision tree. ${ }^{36}$

But even if one follows the decision tree model of deference doctrine, it remains uncertain how to handle Chevron Step One-the injunction to the courts, that is, of deciding whether Congress has spoken with sufficient clarity on the question at issue so as to foreclose the agency's interpretation as a matter of law. Courts are told to apply "traditional tools of statutory interpretation" to determine if the agency under review has acted within the bounds of what is statutorily permissible. ${ }^{37}$ One puzzle is whether these tools include Skidmore deference.

In his contribution, Peter Strauss argues that, even at Step One, some measure of deference is owed to the agency's position. ${ }^{38} \mathrm{He}$ concludes that Skidmore deference is appropriate at Step One because the rationales for giving weight to an agency's view-namely, respecting the agency's possible involvement in drafting the relevant statute and its unique obligations and perspective regarding often complex statutory schemesare apposite even at this stage. He finds it ominous that such deference goes largely unmentioned in City of Arlington v. FCC, ${ }^{39}$ in which the Court held the Chevron framework applicable even to questions of statutory interpretation that might be thought "jurisdictional." Professor Strauss reads the majority's dicta about Step One as implying that only textualist statutory analysis is appropriate under Step One, and that such an analysis is to be deployed "rigorously" 40 _ by implication, de novo — by the court.

Professor Strauss reads the dissent also as limiting Skidmore. The dissent says: "[T]he question whether an agency enjoys [interpretive] authority must be decided by a court, without deference to the agency." 41 Professor Strauss reads this as a repudiation of Skidmore deference on a question that he takes to be, in Chief Justice Roberts's view, a Chevron Step One question. ${ }^{42}$ As Professor Strauss reads nearly two centuries of precedent, however, there is no category of judicial review of statutory interpretation by government administrators that is entirely deference-free. If present on any Step One question, including a jurisdictional question, the factors that give an agency's interpretation the "power to persuade, if [not] to control," 43 ought still to be given weight.

36. Hickman, supra note 21, at 542-45.

37. Chevron U.S.A. Inc. v. Natural Resources Defense Council, Inc., 467 U.S. 837, 843 n.9 (1984).

38. Peter L. Strauss, In Search of Skidmore, 83 FordHAM L. REV. 789 (2014).

39. 133 S. Ct. 1863, 1872-73 (2013).

40. Id. at 1874 .

41. Id. at 1878 (Roberts, C.J., dissenting).

42. Strauss, supra note 38, at 796.

43. Skidmore v. Swift \& Co., 323 U.S. 134, 140 (1944). 
Professor Merrill takes a very different tack in his contribution. ${ }^{44} \mathrm{He}$ embraces instead the core thesis of the Roberts dissent in City of Arlington, arguing that, before a court owes any agency Chevron deference on any question at all, the court must confirm on its own something more than a legislative delegation to speak with the force of law in a general sense. Rather, the court must find a delegation of interpretive authority over the particular statutory provision in question - which is what the parties called a jurisdictional issue. A court cannot pursue this inquiry in quite the way it attacks a Chevron Step One question because factors other than the statutory language at issue may appropriately persuade a court that no interpretive delegation should be inferred. What Professor Merrill calls "boundary maintenance," an "important function of judicial review,"

includes ... important precepts, such as the requirements that agencies honor individuals' rights, abstain from interfering with authority given to other agencies, abide by relevant obligations contained in international law, and respect the traditional prerogatives of state and local governments. ${ }^{45}$

Where the potential exists for crossing institutional boundaries improperly with regard to the implementation of a particular statutory provision, courts might well conclude that judges are the most qualified umpires to determine if the agency has asserted its authority permissibly. This formulation implicitly recognizes a class of cases where (1) Congress may not have so clearly addressed the issue the agency addresses as to result in a clear boundary line that the agency must obey - that is, the statute at issue may be ambiguous - but (2) despite the ambiguity of the provision at issue, it is unreasonable to treat the agency as enjoying delegated authority to give the provision any reasonable interpretation it chooses.

Professor Merrill's approach may or may not contradict Professor Strauss's understanding of how to approach run-of-the-mill Chevron Step One questions. On one hand, the argument that a statute, properly read, forecloses an agency interpretation might be re-cast as an argument that the statute's clear meaning belies any delegation of authority to the agency to depart from that clear meaning. This is why the majority opinion in City of Arlington insists that there is no difference between jurisdictional challenges to an agency's interpretation of law and any other kind of challenge. ${ }^{46}$ If all Step One issues are jurisdictional, however, then Professor Merrill's approach would preclude according agency views any Skidmore weight at that stage. But Professor Merrill seems to say it is the focus on jurisdiction that is confusing; what is really at issue is the breadth of an implicit delegation. ${ }^{47}$ If so, then, when the only challenge to an agency's delegation is an insistence that it misread a clear statute-in other words, a "pure Step One" challenge-Skidmore deference is

44. Thomas W. Merrill, Step Zero After City of Arlington, 83 Fordham L. Rev. 753 (2014).

45. Id. at 753-754.

46. See City of Arlington, 133 S. Ct. at 1868.

47. See Merrill, supra note 44, at 759. 
unobjectionable. Deference would be anomalous only if there were some institutional factor beyond the precise text in dispute to question whether Congress would have preferred the agency over a court as the primary interpreter of what a challenged provision means.

Professor Beermann has an explanation for the persistence of such confusions as to Chevron's correct implementation: he thinks it incoherent or, at least, "inherently unstable." 48 He chides the Roberts Court for failing still to provide "clear instructions" on "when [Chevron] applies and when it does not." 49 He bemoans a lack of clarity as to the relationship between deferential review under Step Two and the "hard look" approach of APA arbitrary and capricious review. ${ }^{50} \mathrm{He}$ finds that decisions examining agency discretion to adopt statutory interpretations that courts had rejected pre-Chevron "do not appear to be constrained by the Chevron framework or any other discernible set of interpretive principles." 51 Challenging the theoretical bases for Chevron as "fictional," 52 he argues that the chief effect of the fight over deference principles is to obscure underlying disagreements as to the substantive merits of the actions being revieweddisagreements that better explain various Justices' votes than do the Justices' disputes over deference doctrine. ${ }^{53}$

While taking no position on the theoretical coherence of Chevron, James Brudney's study of 730 Supreme Court decisions to evaluate the use of Chevron and Skidmore in the workplace law context ${ }^{54}$ lends support to the Beermann hypothesis that substance may trump neutral deference doctrine in predicting Justices' votes in statutory interpretation cases. The study may also suggest that, despite the torrent of citations and law review articles unleashed by Chevron, it portended no real change in the Court's overall treatment of agency deference. On one hand, looking at the three key

48. Beermann, Chevron at the Roberts Court, supra note 17 , at 750.

49. Id. at $742-43$.

50. Id. at $741-50$.

51. Id. at 741 .

52. Id. at 750 .

53. In his symposium contribution, Peter Shane, while not tackling the precise issue in City of Arlington, takes a more sanguine view of Chevron than does Professor Beermann. Chevron's central premise, he argues, is the distinction that underlies the foundational nondelegation doctrine - a distinction between statutory boundaries that an agency is required to interpret correctly and an area of statutory discretion within which an agency is required only to act reasonably. Peter M. Shane, Chevron Deference, the Rule of Law, and Presidential Influence in the Administrative State, 83 FordHAM L. REv. 679, 685-86 (2014). He appears untroubled by the Court's failure to draw clear lines between Chevron Step Two review and APA arbitrary and capricious review because an agency's arguments for the permissibility of its statutory reading are likely to track closely what would be its arguments for the reasonableness of its implementation strategy. Id. at 688-90. Whether a court uses one or the other rubric for its decision is most likely to turn on whether the challenge to agency reasonableness is based on an alleged lack of principled connection between agency action and the purposes and boundaries set in the relevant statute-which makes the dispute look interpretive - or whether the agency is assertedly lacking in its demonstration that the connections it posits actually exist on the record, which sounds more like an arbitrary and capricious challenge.

54. James J. Brudney, Chevron and Skidmore in the Workplace: Unhappy Together, 83 FORDHAM L. REV. 497 (2014). 
agencies in making workplace law - the National Labor Relations Board (NLRB), the U.S. Equal Employment Opportunity Commission (EEOC), and the U.S. Department of Labor (DOL) - Professor Brudney finds that the Court's formal post-Chevron-and-Mead articulation of deference frameworks for each agency closely tracks the Court's pre-Chevron treatment of each agency. That is, the NLRB benefited from fairly generous judicial deference which then became Chevron deference, the EEOC was subject to more searching review prior to getting Skidmore deference in Title VII cases, and the DOL has been given more variable treatment (pre- and post-Chevron) depending on the statutory program involved. ${ }^{55}$ At the same time, however-and in contrast to pre-Chevron years-agency win rates are higher when the agency position favors employers as opposed to employees. ${ }^{56}$

Furthermore, even though the Court's approach in workplace law cases frequently invokes the kinds of factors entailed in Chevron and Skidmore analysis, in cases where the majority or dissent relied on agency deference, two in three such cases made no reference to Chevron or Skidmore.57 Professor Brudney is careful to point to factors other than the Justices' economic ideology that may help explain his observations, but it seems hard to gainsay the importance of the Justices' substantive views in these cases. The possibility, to which Professor Beermann refers, seems realistic that the deference frameworks are not really operating to discipline the courts (or at least the Supreme Court) and make agency deference a more influential factor in judicial review.

\section{THE IMPACT OF CHEVRON OUTSIDE THE COURT}

A number of symposium contributors focus on second-generation issues related to Chevron deference-i.e., the effect Chevron has had on (A) the theory and practice of legislative drafting and statutory interpretation; (B) agency behavior within the administrative state; and (C) the development of state administrative law. Each will be addressed in turn.

\section{A. Chevron in Congress}

As to legislative drafting, judicial deference to administrative interpretations of law is based on Congress's express or implied delegation of interpretative authority to the agency; until recently, little had been done to evaluate Chevron's influence on legislative drafting. Two contributors focus on the effect of Chevron within Congress.

Professor Gluck continues her pathbreaking work on the role of Chevron in legislative drafting and statutory interpretation-focusing in this symposium on what Chevron can teach us about the rest of statutory interpretation. ${ }^{58}$ But before turning to her contribution, any symposium on

55. Id. at 498-99.

56. Id. at 512 tbl.3.

57. Id. at 501 .

58. Gluck, supra note 15. 
Chevron would be incomplete without first noting the key findings from Professor Gluck's prior empirical study with Lisa Schultz Bressman on congressional drafting, in which they asked 137 congressional drafters forty-five questions about their knowledge of administrative law and the extent to which it influences their drafting. 59

Chevron, it turns out, was the most known, by name, of any interpretive tool in the Bressman and Gluck study. The overwhelming majority (82 percent) of congressional drafters surveyed were aware of this background principle. ${ }^{60}$ Of those interviewed, 58 percent said Chevron plays a role when drafting; 31 percent indicated in comments that statutory ambiguity results in judicial deference to agency interpretations; and 29 percent reported that Chevron forces them to think about how precisely to draft. ${ }^{61}$ Nine in ten (91 percent) stated that one reason for statutory ambiguity is to delegate decision making to agencies, with lack of time (92 percent), complexity of issue (93 percent), and need for consensus (99 percent) being other predominant reasons. ${ }^{62}$

Mead and Skidmore are a somewhat different story. Unlike Chevron's 82 percent name recognition, 20 percent or less knew Skidmore and Mead by name; 18 percent knew Skidmore but not Mead; and 8 percent knew Mead but not Skidmore. 63 Yet, by concept, Professors Gluck and Bressman conclude that Mead was a "big winner," in that 88 percent indicated that the delegation signal emphasized in Mead-congressional authorization of agency rulemaking - is always or often relevant to whether drafters intend for an agency to have interpretative authority. ${ }^{64}$

Professors Bressman and Gluck concluded that Chevron itself is not the reason drafters leave ambiguities; instead, the reasons mirror those articulated in Chevron - delegation of decision making, implementation, expertise, etc. ${ }^{65}$ But these findings cast serious doubt on the longstanding view that Chevron is merely a legal fiction. Congress appears to be quite familiar with Chevron (or at least the congressional drafters surveyed are) either intentionally leaving ambiguities to delegate decision making to agencies or at least knowingly legislating against this background Chevron default. And congressional drafters understand the Mead factors and believe that they are relevant to deriving congressional intent to delegate.

59. See Abbe R. Gluck \& Lisa Schultz Bressman, Statutory Interpretation from the Inside-An Empirical Study of Congressional Drafting, Delegation, and the Canons: Part I, 65 Stan. L. ReV. 901 (2013) [hereinafter Gluck \& Bressman, Part I]; Lisa Schultz Bressman \& Abbe R. Gluck, Statutory Interpretation from the Inside-An Empirical Study of Congressional Drafting, Delegation, and the Canons: Part II, 66 Stan. L. REV. 725 (2014).

60. Gluck \& Bressman, Part I, supra note 59, at 995.

61. Id. at 996.

62. Id. at 997.

63. Id. at 995 (footnotes omitted). As Professors Gluck and Bressman note, however, these numbers may be lower based on a change in how the questions were asked in the survey. See id. at 995 n.337.

64. Id. at 999.

65. Id. 
As Kent Barnett documents in his symposium contribution and elsewhere, not only do congressional drafters know about these administrative law deference doctrines when drafting, but in at least one instance Congress has actually codified a judicial review standard less deferential than the Chevron default.66 In the Dodd-Frank Wall Street Reform and Consumer Protection Act (Dodd-Frank), Congress directed courts to review under the less deferential Skidmore standard any decision to preempt state law made by the Office of the Comptroller of the Currency (OCC) ${ }^{67}$ It should be interesting to see whether Congress continues to tinker with these judicially created deference doctrines, and perhaps even more interesting to see how the Supreme Court responds. As Professor Gluck notes in her contribution, that "Congress could legislate some different version of Chevron" distinguishes the administrative law deference doctrines from other traditional tools of statutory interpretation where courts have resisted the idea of methodological stare decisis. ${ }^{68}$

In her contribution, Professor Gluck builds on her prior empirical study on congressional drafters - as well as on her other work on statutory interpretation more generally ${ }^{69}$ - to distinguish Chevron (and related administrative law doctrines) from other statutory interpretation tools. ${ }^{70}$ She makes six main observations about those differences and what they teach us about statutory interpretation: (1) As noted above, Chevron is a precedent, whereas the other tools are usually considered "rules of thumb"; yet (2) Chevron in essence codifies the rules of thumb by directing that they apply at Step One. (3) Unlike the other interpretive tools, the Court has attempted to ground Chevron in actual congressional intent, and (4) by focusing on actual legislative intent, the Court has influenced how Congress legislates by encouraging Congress to delegate with formal process if it intends for Chevron to apply to particular agency statutory interpretations. (5) While the Court has guarded jealously its control over statutory interpretation from Congress, the Court has expressly ceded such power to federal agencies by holding that a subsequent agency interpretation of an ambiguous statute the agency administers trumps a prior judicial

66. Kent Barnett, Codifying Chevmore, 89 N.Y.U. L. REV. (forthcoming 2015), available at http://ssrn.com/abstract $=2405016$; Kent Barnett, Improving Agencies' Preemption Expertise with Chevmore Codification, 83 FordHAM L. REv. 587 (2014) [hereinafter Barnett, Preemption and Chevmore].

67. Barnett, Preemption and Chevmore, supra note 66, at 599-600 (citing 12 U.S.C. $\S 25 \mathrm{~b}(\mathrm{~b})(5)(\mathrm{A})(2012))$.

68. Gluck, supra note 15, at 614-17.

69. See Abbe R. Gluck, Intersystemic Statutory Interpretation: Methodology As "Law" and the Erie Doctrine, 120 YALE L.J. 1898, 1910 (2011); Abbe R. Gluck, Intrastatutory Federalism and Statutory Interpretation: State Implementation of Federal Law in Health Reform and Beyond, 121 Yale L.J. 534 (2011); Abbe R. Gluck, The Federal Common Law of Statutory Interpretation: Erie for the Age of Statutes, 54 WM. \& MARY L. REV. 753 (2013); Abbe R. Gluck, The States As Laboratories of Statutory Interpretation: Methodological Consensus and the New Modified Textualism, 119 YALE L.J. 1750 (2010) [hereinafter Gluck, States As Laboratories of Statutory Interpretation].

70. Gluck, supra note 15, at 609-11. 
interpretation. ${ }^{71}$ (6) Yet, the Court's understanding of congressional drafting is outdated, especially in assuming congressional delegation to one federal agency at a time when Congress often delegates to multiple agencies and other actors. ${ }^{72}$

Following Professor Gluck's lead, in the years to come we expect more scholars of statutory interpretation to look to Chevron and related doctrines for lessons about advancing the theory and practice of statutory interpretation. After all, as Professor Gluck's observations underscore, Chevron provides a natural experiment of sorts between an interpretive tool with precedential force and the rest of the traditional tools that lack such force. And because Chevron is a precedent that incorporates nonprecedential rules of thumb at its first step, no doubt the future will see many, many more law review articles, legal briefs, and judicial opinions on which tools of statutory interpretation should apply to determine congressional intent at Step One. Hopefully the realities of the modern-era legislative process will play a more prominent role in the further development of the Chevron deference regime.

\section{B. Chevron Within the Regulatory State}

Whereas most scholarship on Chevron has focused on Chevron in the courts and some on Chevron in Congress, little attention has been paid to the impact of Chevron inside the administrative state. Three contributions to this symposium focus extensively on this topic, which will no doubt receive much more attention in the years to come. All three of these contributions also assess Chevron as a legitimizing function within the modern administrative state.

First, Christopher Walker explores how thirty years of Chevron and related administrative law doctrines have shaped agency rule drafting and, in particular, whether the expectation of Chevron deference (as opposed to Skidmore deference or de novo review) encourages federal agencies to be more aggressive in their interpretive practices. ${ }^{73}$ He reports the Chevronrelated findings from a 195-question survey he conducted of 128 federal agency rule drafters at seven executive departments and two independent agencies. Of those who responded to the survey, nearly all (94 percent) were aware of Chevron by name, and four in five ( 81 percent) were aware

71. Nat'l Cable \& Telecomms. Ass'n v. Brand X Internet Servs., 545 U.S. 967, 982-83 (2005).

72. Gluck, supra note 15, at 609-11. The Court's "Schoolhouse Rock!" understanding of lawmaking, arguably, is not limited to the legislative process. Id. at 611. As Aaron Saiger observes in his contribution, Chevron's focus on political accountability as a justification for Chevron 'troublingly and casually conflates the President, the 'administration,' and the agencies." Aaron Saiger, Chevron and Deference in the State Administrative Law, 83 FORDHAM L. REV. 555, 564 (2014).

73. Christopher J. Walker, Chevron Inside the Regulatory State: An Empirical Assessment, 83 FordHAM L. REV. 703 (2014) [hereinafter Walker, Chevron Inside the Regulatory State]. The full findings from the empirical study are reported in Christopher J. Walker, Inside Agency Interpretation, 67 STAN. L. REV. (forthcoming 2015), available at http://ssrn.com/abstract=2501716. 
of Skidmore. ${ }^{74}$ Although Mead was not as well known by name (at 61 percent), the rule drafters confirmed that they understood the basic principles articulated in Mead-i.e., congressional authorization of rulemaking or formal adjudication (at 84 percent) and the agency's use of it (at 80 percent) affect whether an agency's interpretation receives Chevron deference. ${ }^{75}$ To put those numbers in perspective, Chevron was the most known of more than twenty interpretive tools included in the survey, and Mead came in fourth place (behind only Chevron, the whole act rule, and the ordinary meaning canon). ${ }^{76}$ These findings are similar to those of the congressional drafters surveyed in the Bressman and Gluck study, discussed in Part II.A, and similarly demonstrate how Chevron has become a principal tool for drafters and interpreters in federal agencies as well as in Congress.

Moreover, nine in ten (90 percent) agency rule drafters indicated that Chevron plays a role in their rule-drafting decisions. A similar number agreed or strongly agreed that they think about judicial review when drafting statutes (at 87 percent) and that their chances in court are better under Chevron than Skidmore or no deference (at 83 percent). When asked if federal agencies are more aggressive in their interpretive efforts if they know Chevron applies, two in five (38 percent and 43 percent, depending on how the question was phrased) strongly agreed or agreed, and another two in five (45 percent and 40 percent) somewhat agreed. ${ }^{77}$ In other words, these findings provide support for the propositions that the judicial review standard matters as an ex ante check on agency rule-drafting behavior and that an agency may draft differently if a court (or Congress, as further discussed in Part III) tells the agency that Chevron or Skidmore applies. As Professor Walker concludes, understanding how federal agencies draft differently under distinct deference regimes is not merely academic but may well go to the heart of the regulatory state's democratic legitimacy:

After all, Chevron and related doctrines attempt to strike a proper separation of powers balance between the branches of government by patrolling the delegation of authority from the principal (Congress) to its unelected agents in the regulatory state. Whether the deference standards help to faithfully control Fourth Branch lawmaking goes to the democratic (and perhaps constitutional) legitimacy of the modern administrative state. 78

In her contribution, Emily Hammond further explores Chevron's role in legitimizing administrative governance. As Professor Hammond explains, " $\mathrm{t}]$ he governing paradigm is that judicial review is a necessary component of administrative legitimacy" because, among other things, "[i]t acts as an ex ante check on agency behavior by incentivizing agencies to promote participation, engage in deliberation, and set forth their reasoning

74. Walker, Chevron Inside the Regulatory State, supra note 73, at 715-17 \& fig.1.

75. Id. at $717-18$ \& tbl.1.

76. Id. at $717-18$.

77. Id. at $722-25$ \& fig. 3 .

78. Id. at 728-29 (footnote omitted). 
transparently in the first instance." 79 Building on her prior work with David Markell, ${ }^{80}$ Professor Hammond explores the generality of Chevron's legitimizing function-moving the conversation to unreviewable exercises of authority to "pinpoint just what it is courts provide when they undertake review." 81

To see Chevron as a generality principle rather than a specialized judicial review doctrine of agency statutory interpretation, Professor Hammond surveys a number of second-order contexts-i.e., the interpretation of contracts, settlements, and land patents-where courts have invoked Chevron. 82 Based on the rationales utilized in these contexts, she offers three metrics for measuring the legitimacy of agency action that is either unreviewable or rarely reviewable: (1) whether the agency acts within its scope of statutory authority, (2) exercising its expertise to provide uniformity in law (3) with sufficient procedures in place. ${ }^{83}$ Although based on Chevron, these legitimizing metrics sound a lot more like the Skidmore factors. This perhaps should come as no surprise as Skidmore itself is about the agency's "power to persuade"-or legitimize — based on "the thoroughness evident in [the agency's] consideration, the validity of its reasoning, its consistency with earlier and later pronouncements," and so forth. ${ }^{84}$ It is also worth noting that the Chevron justification of political accountability "plays little to no role in the second-order Chevron decisions." 85 Professor Hammond observes that, "[a]s a descriptive matter, this omission invites rethinking about the place of presidential control in administrative law doctrine." 86

Peter Shane's exploration of the President's role in the Chevron deference regime picks up precisely on this point. ${ }^{87}$ He begins by arguing that Chevron fits well with a rule-of-law account of the administrative state that emphasizes the duty of courts to implement Congress's administrative designs. Far from regarding the delegation-based rationale for Chevron as "fictional," he relies on the Bressman and Gluck study noted in Part II.A as substantiating that the delegation rationale meshes well with the reality of statutory drafting. Because the Court's post-Chevron jurisprudence so clearly establishes delegation and not political accountability as the primary theoretical underpinning for Chevron, it is important for courts specifically to respect Congress's decisions to vest administrative decision making authority in officials other than the President.

79. Emily Hammond, Chevron's Generality Principles, 83 FoRdHAM L. Rev. 655, 656 (2014).

80. Emily Hammond \& David L. Markell, Administrative Proxies for Judicial Review: Building Legitimacy from the Inside-Out, 37 HARV. ENVTL. L. REV. 313 (2013).

81. Hammond, supra note 79 , at 673-74.

82. Id. at $666-73$.

83. Id. at 673-78.

84. Skidmore v. Swift \& Co., 323 U.S. 134, 140 (1944).

85. Hammond, supra note 79 , at $677-78$.

86. $I d$.

87. Shane, supra note 53. 
That is, contrary to "unitary executive theorists," Professor Shane does not think the President enjoys any constitutional authority to direct agency action in domestic affairs beyond such license as Congress gives the President. ${ }^{88}$ As a result, courts need to be careful before according Chevron deference to agency interpretations of law that are revealed to be the product of White House pressure where the record reveals the agency's earlier preference for a different interpretation that itself would have been reasonable enough to warrant Chevron deference. In such cases, Professor Shane would have the reviewing court remand to the agency to choose, after further consideration and a supplemented record, between its original interpretation and the interpretation on which the White House insisted. ${ }^{89}$ The only exception he thinks consistent with a rule-of-law view of Chevron would be the presumably rare case in which the White House had required an agency to pursue a permissible interpretation that the agency would nonetheless not have preferred, but which makes it possible for other agencies to discharge some related administrative responsibilities in a better coordinated fashion. Deferring to White House influence in such a case would respect a presidential power of interagency coordination that is reasonably traceable to his role as chief executive. ${ }^{90}$

\section{Chevron in the States}

Aaron Saiger provides a unique perspective on the impact-or, better said, lack thereof- of Chevron on state administrative law. ${ }^{91}$ After reviewing a number of state-by-state surveys on Chevron and state-level administrative law, he concludes: "Although a significant number of states have adopted deference doctrines that closely approximate Chevron's, few have endorsed it wholeheartedly. Only a few have rejected it explicitly either, but the majority of the states have deference doctrines meaningfully different from Chevron's." 92 He then explores the reasons why states have not embraced Chevron in state-level administrative law.

Professor Saiger ultimately concludes that the differences between the structures of federal and state governments make Chevron unsuitable for blanket state-level adoption. ${ }^{93}$ In particular, state judges are not similarly situated to federal judges, in that they lack life tenure and thus tend to be closer to the political branches. Most states lack a unitary executive but, instead, have a number of state-wide elected executive officials, all of which have their distinct administrative functions and intraexecutive checks and conflicts. And state legislatures, while most similar of the three

88. Peter M. Shane, Madison's Nightmare: How Executive Power Threatens AmERicAn DEMOCRACY 32-42 (2009). For the contrary view, see SteVEn G. CALABresi \& Christopher S. Yoo, The Unitary Executive: Presidential Power From Washington TO Bush (2008).

89. Shane, supra note 53 , at 702 .

90. Id.

91. See Saiger, supra note 72.

92. Id. at 582 .

93. See id. at 560-70 (exploring the differences in all three branches). 
branches to their federal counterpart, have vastly different approaches to nondelegation rules. ${ }^{94}$

Despite the lack of adoption at the state level, Professor Saiger argues that states should not ignore Chevron. Much like Professor Gluck's assertion that we can learn a lot from Chevron about the other tools of statutory interpretation, Professor Saiger argues that Chevron has a lot to teach states about judicial review of agency statutory interpretations: "Chevron is a model for states not by virtue of its holding but of its multiinstitutional mode of analysis." 95 Indeed, if modified to the structure of the particular state government, he suggests that " $[t]$ he particular way in which Chevron balances between politics, the rule of law, and bureaucratic effectiveness is a worthy model for states to consider." 96

There is little doubt that the next thirty years will see much experimentation with Chevron in the laboratories of democracy as states attempt to control state-level bureaucracy. But hopefully the breakthroughs (and failures) in these laboratories will also be explored at the federal level. For instance, as Professor Saiger notes and Professor Gluck documents elsewhere, many states have embraced methodological stare decisis in statutory interpretation that the federal system has rejected. ${ }^{97}$ More analysis of those experiments - and how they might play out on the federal level where the governmental structure differs substantially—is warranted.

\section{THE INTERPLAY BETWEEN CHEVRON AND FEDERALISM}

With the continued (and perhaps renewed) scholarly interest in federalism generally, it is no surprise that two contributors also focus on the effect of federalism on judicial review of agency statutory interpretations.

Miriam Seifter tackles the topic head on, arguing that federalism should play no role at Chevron Step Zero. ${ }^{98}$ Building on her prior work on the role of states in the federal regulatory process, ${ }^{99}$ she explains that federalism concerns are varied and diverse. Accordingly, a one-size-fits-all default rule against Chevron when federalism concerns are implicated-thus relegating such agency interpretations to either Skidmore deference or de novo review-would do more harm than good. As she explains, the question is not whether federalism should be considered in Chevron cases, but whether there is any Step Zero test that can direct federalism analysis to the most competent institution. Federalism's heterogeneity suggests that this endeavor would be fraught, and thus would cause needless harm to the

94. Professor Saiger also contrasts the various state statutes and judicial standards of review of state agency action with their federal counterparts. See id. at 570-79.

95. Id. at 583 .

96. Id.

97. Id. at 584 (citing Gluck, States As Laboratories of Statutory Interpretation, supra note 69 )

98. Miriam Seifter, Federalism at Step Zero, 83 FordHAM L. Rev. 633 (2014).

99. Miriam Seifter, States, Agencies, and Legitimacy, 67 VAND. L. ReV. 443 (2014); Miriam Seifter, States As Interest Groups in the Administrative Process, 100 VA. L. REV. 953 (2014). 
coherence and simplicity that make Chevron useful. Considering federalism in Chevron's ordinary two steps (and under APA arbitrary and capricious review), Professor Seifter argues, allows courts to police agency interpretations effectively and at less cost. ${ }^{100}$

Professor Barnett's contribution to this symposium provides an interesting contrast. As he explains, Congress in Dodd-Frank has directed courts to review OCC preemption decisions under the less deferential Skidmore standard. ${ }^{101}$ In other words, Congress has instructed that Chevron does not apply to these decisions at Step Zero-precisely what Professor Seifter asserts courts should not do. And, as Professor Barnett argues, "[a]pplying Skidmore deference to agency preemption recognizes agencies' technical and administrative expertise while accounting for their lack of experience in weighing federalism values in their preemption analysis."102 His argument is not that Chevron should never apply to agency preemption decisions, but that Congress should encourage agencies to develop such expertise by codifying Skidmore deference where agency inexpertness is evident. As Professor Barnett notes, "[t]he OCC's preemption of state consumer-protection laws provides perhaps the most striking example of inexpertness, preemption, and a congressional response."103 He concludes by lauding the value of Chevmore codification:

Going forward, Congress can improve an agency's use of expertise as to preemption specifically and other matters generally. Congress can lead agencies to consider how their technical and administrative expertise interacts with federalism values by requiring agencies to consider those values and consult with affected parties [including states]. Congress can also improve agencies' use of administrative and technical expertise both inside and outside of the preemption context by using Chevron deference as a "carrot" [and Skidmore as a "stick"] for agencies to develop and apply their expertise. 104

It is not clear that Professors Barnett and Seifter actually disagree in any fundamental way. Chevmore codification is different from blanket consideration of federalism concerns by courts at Chevron at Step Zero; it is a narrow, specific application codified by Congress as to one particular agency. Perhaps they would agree that only the congressional principalnot the judicial agent - should decide when Chevron does not apply to an agency statutory interpretation that implicates federalism concerns (or other areas where an agency has demonstrated incompetence). In all events, it will be interesting to see whether Chevmore codification becomes commonplace - as opposed to a one-off anomaly — and, if so, whether the

100. Seifter, supra note 98 , at $652-54$.

101. Barnett, Preemption and Chevmore, supra note 66, at 587 (citing 12 U.S.C. $\S 25 \mathrm{~b}(\mathrm{~b})(5)(\mathrm{B})(2012))$.

102. Id. at 594 (citing Nina A. Mendelson, Chevron and Preemption, 102 Mich. L. Rev. 737, 797 (2008)).

103. Barnett, Preemption and Chevmore, supra note 66, at 596.

104. Id. at 604 . 
Court will push back on congressional attempts to alter the judicially created and calibrated Chevron deference regime. ${ }^{105}$

\section{CONCLUSION: CHEVRON: BIG DEAL? GOOD DEAL? BAD DEAL?}

At the March 2014 symposium, the panel entitled "Chevron: Big Deal? Good Deal? Bad Deal?" featured Professors Beermann, Merrill, and Strauss. Not surprisingly, however, a variety of responses are discernible from most, if not all, the contributors.

Professor Beermann stands out in the group for his unequivocal negative assessment of Chevron. Three decades, in his judgment, have revealed that Chevron rests on unstable premises, obscures and distracts from what is often at stake in statutory interpretation cases, and is applied by the Supreme Court so inconsistently as to leave lower courts (and lawyers) more perplexed than well guided. ${ }^{106}$ As discussed in Part I, Professor Brudney's analysis is arguably consistent with the obscurity point. Yet his observation that the formal deference accorded the different agencies engaged in making workplace law did not really change from the preChevron to the post-Chevron period suggests that the judicial impact of Chevron might well be overestimated, especially with regard to the Supreme Court itself. ${ }^{107}$

Professors Strauss and Shane seem to be of the mind that, Justice Scalia's insistence to the contrary notwithstanding, Chevron was not intended and should not be read as a major displacement of prior administrative jurisprudence. Professor Strauss may worry that a misinterpretation of Chevron could undermine judicial respect for a centuries-old doctrine that agency interpretations of the statutes they administer ought always to be eligible for some weight in the course of judicial review. ${ }^{108}$ Professor Merrill, however, does not see in City of Arlington the same inattention to Mead/Skidmore deference that Professor Strauss bemoans. Indeed, he thinks it significant that the majority opinion penned by Justice Scalia includes what is arguably an acquiescent nod to Mead. ${ }^{109}$ Professor Shane, as noted above, thinks Chevron simply plays out a logic of judicial review already implicit in the nondelegation doctrine. His main criticism of

105. As Professor Walker explores in his contribution, it is also an open question whether Chevmore codification will change agency interpretive practices, especially in the preemption context. See Walker, Chevron Inside the Regulatory State, supra note 73, at 721 (reporting that "over half of the rule drafters surveyed already do not assume Chevron deference applies to agency preemption decisions - and, indeed, half apply the presumption against preemption when there is an ambiguity-[such that] congressional modification from Chevron space to Skidmore weight would have no effect on agency statutory interpretation at least with respect to those rule drafters").

106. Beermann, Chevron at the Roberts Court, supra note 17, at 731-33.

107. Brudney, supra note 54, at 498.

108. Strauss, supra note 38.

109. Merrill, supra note 44, at 757. 
Chevron, if it be one, is that its deference mandate is expressed in rhetoric that makes it sound more frequently consequential than it is likely to be. ${ }^{110}$

For their part, Professors Hickman and Merrill also appear to see Chevron as fitting in a useful and not especially disruptive way into the jurisprudence of judicial review. Now that Mead has expressly elaborated on Chevron by incorporating the Merrill-Hickman Step Zero inquiry into the nature of the authority Congress delegated to the agency under review, Professor Hickman finds lower courts turning helpfully to the cases, most often in a decision tree mode, but sometimes also (as does the Supreme Court) in a manner more reminiscent of Justice Breyer's multiple factors approach. ${ }^{111}$ Professor Merrill is chiefly critical of the Court's failure to take seriously enough the delegation-based rationale for Chevron, but argues that the emphasis on delegation that was central to Chief Justice Roberts's dissent in City of Arlington ought to prevail over time. ${ }^{112}$

Perhaps the most surprising conclusion implicit or explicit in the various symposium contributions, however, is that the "big deal" of Chevron is most evident if one looks beyond its impact on the federal courts to its impact on the other federal branches and its potential impact on the states. The survey-based analyses that Professors Gluck and Walker undertook, respectively, regarding the drafting staff in Congress and in the agencies, confirms Chevron's role as a widely understood default principle that affects how statutes and regulations are drafted. ${ }^{113}$ Professor Walker's finding that rule makers may draft more aggressively in contexts they recognize as Chevron-eligible ${ }^{114}$ resonates with Professor Hammond's observation that deference doctrine affects the legitimacy of agency decision making by intensifying or relaxing ex ante incentives for conscientious agency behavior. ${ }^{115}$ Because courts now apply Chevron Step Two analysis with the rigor of "hard look" review under the APA's arbitrary and capricious standard, it seems likely that agency lawyers worry less, post-Chevron, about showing that their interpretations are legally compelled and more about showing that their justifications find grounding in the record. As Professor Barnett argues, Chevron and Mead together

110. Peter M. Shane, Ambiguity and Policy Making: A Cognitive Approach to Reconciling Chevron and Mead, 16 VILL. EnvTL. L.J. 19 (2005) (arguing that Chevron deference, properly understood, should be outcome-decisive only in those cases in which a judge is persuaded that there exists an interpretation of the relevant statute that is not legally compelled, but nonetheless superior to the agency's reasonable, but less attractive interpretation).

111. Hickman, supra note 21, at 547-53. Professor Seifter would apparently hold out little hope for a decision tree approach in cases implicating administrative federalism. She argues that Chevron must turn to the use of standards (instead of rules) in the federalism context, underscoring that "federalism inquiries and values tend to be multifaceted and nuanced in ways that make them poor fits for more formalistic, rule-bound features of administrative law." Seifter, supra note 98 , at 638.

112. Merrill, supra note 44, at 757-58.

113. Gluck \& Bressman, Part I, supra note 59, at 995-99; Walker, Chevron Inside the Regulatory State, supra note 73, at 715-17 \& fig.1.

114. Walker, Chevron Inside the Regulatory State, supra note 73, at 722-25 \& fig.3.

115. Hammond, supra note 79, at 673-74. 
have also given Congress an effective vocabulary for calibrating the deference it wants courts to give to agencies when Congress wants to make that choice explicit. ${ }^{116}$

Professor Saiger finds that Chevron has been less of a big deal in the states than it deserves to be. ${ }^{117}$ Like much of federal separation of powers jurisprudence, Chevron cannot and should not be adopted by states mechanically because state constitutions differ as to government organization, and the institutional characteristics of state courts, legislatures, and agencies may differ sufficiently from those of the federal government to warrant somewhat different understandings for the appropriate occasions for and scope of deference to be accorded agency views of state law. Yet, as noted above, Chevron's analysis of the issues posed by deference doctrine provide a model of sorts for how state courts might sort out an appropriate balance between politics, the rule of law, and agency expertise. As state governments continue to grow in size and range of activity, it seems inevitable that scholars will increasingly turn their attention to this very question.

There is, of course, one way in which the "big deal" of Chevron is unassailable. It has energized a virtual cottage industry within the academy of reexamining - both descriptively and normatively - the relationship of courts and agencies and the appropriate role and recognition in the administrative state of rule of law values. Administrative law is built around - indeed, necessitated by - the inevitability and ubiquity of agency discretion in contemporary governance. Judicial review, as Professor Hammond says, is widely taken to be an essential component to the legitimacy of administrative governance. ${ }^{118}$ So long as these things are true, the issues highlighted by this symposium will remain ripe for discussion and are likely to sustain symposia for many more of Chevron's birthdays.

116. Barnett, Preemption and Chevmore, supra note 66, at 587.

117. Saiger, supra note 72 , at 582-84.

118. Hammond, supra note 79 , at 673-74. 